\title{
Association between statin use and mortality risks during the acute phase of ischemic stroke in patients admitted to an intensive care unit
}

\author{
Associação entre o uso de estatina e risco de mortalidade durante a fase aguda do acidente \\ vascular cerebral isquêmico em pacientes admitidos em uma unidade de terapia intensiva \\ Natalia Eduarda FURLAN', Juli Thomaz de SOUZA', Silméia Garcia Zanati BAZAN', \\ Roberto Jorge da Silva FRANCO', Gustavo José LUVIZUTTO², Ana Lúcia GUT', \\ Gabriel Pinheiro MODOLO ${ }^{3}$, Fernanda Cristina WINCKLER', Luis Cuadrado MARTIN', Rodrigo BAZAN ${ }^{3}$
}

\begin{abstract}
Ischemic stroke is a common cause of death. The role of statins in the secondary prevention of the chronic ischemic stroke phase has been established. However, evidence regarding their efficacy in this phase is limited and contradictory. Objective: To evaluate the association between statin use and mortality risk during the acute phase of ischemic stroke in patients admitted to an intensive care unit. Methods: This was an observational and prospective study of ischemic stroke patients aged $\geq 18$, admitted to an intensive care unit. Medications used during the first 7 days after the ictus, as well as medications used previously, were recorded. The primary outcome was all-cause mortality during the first 7 days. Results: We screened 212 patients and included 97 patients with ischemic stroke in the study period. The mortality rate among patients who used statins during the acute IS phase [14\% (9/63)] was significantly lower than that among patients who did not use statins [41\% (14/34); $p=0.007$ ]. This was confirmed in logistical regression with an 0.19 Odds Ratio - OR [ $p=0.018$; $95 \%$ confidence interval $-95 \% \mathrm{Cl}$ 0.05-0.75]. Patients who died were older, had a higher incidence of acute myocardial infarction, higher scores on the NIHSS and lower systolic blood pressure. Statins and angiotensin converting enzyme inhibitors were used more frequently among survivors. These associations persisted even after adjustment for confounding variables. Conclusion: Statins and angiotensin converting enzyme inhibitors use during hospitalization were independently associated to a lower rate of all-cause mortality in the first 7 days of intensive care unit admission.
\end{abstract}

Keywords: stroke; statins; intensive care unit; mortality.

RESUMO

O acidente vascular cerebral (AVC) isquêmico é uma causa comum de morte. O papel das estatinas na prevenção secundária da fase crônica do AVC isquêmico foi estabelecido. No entanto, as evidências sobre a sua eficácia na fase aguda do AVC isquêmico são limitadas e contraditórias. Objetivo: Avaliar a associação entre o uso de estatinas e o risco de mortalidade durante a fase aguda do AVC isquêmico em pacientes internados em uma unidade de terapia intensiva. Métodos: Estudo observacional e prospectivo de pacientes com AVC isquêmico com idade $\geq 18$ anos, internados em uma unidade de terapia intensiva. Os medicamentos utilizados durante os primeiros 7 dias após o ictus, bem como os medicamentos utilizados anteriormente, foram registrados. 0 desfecho primário foi mortalidade por todas as causas durante os primeiros 7 dias. Resultados: Foram selecionados 212 pacientes e incluídos 97 pacientes com AVC isquêmico no período do estudo. A taxa de mortalidade entre os pacientes que usaram estatinas durante a fase aguda do AVC [14\% (9/63)] foi significativamente menor do que a dos pacientes que não usaram estatinas [41\% (14/34); p=0,007]. Isso foi confirmado na regressão logística com Odds Ratio - OR 0,19 [p=0,018; intervalo de confiança de 95\% - IC95\% 0,05-0,75]. Os pacientes que morreram eram mais velhos, apresentavam maior incidência de infarto agudo do miocárdio, escores mais altos na National Institute of Health Stroke Scale (NIHSS) e menor pressão arterial

\footnotetext{
Universidade do Estado de São Paulo, Faculdade de Medicina, Departamento de Medicina Interna, Botucatu SP, Brazil.

${ }^{2}$ Universidade Federal do Triângulo Mineiro, Departamento de Fisioterapia Aplicada, Uberaba MG, Brazil.

${ }^{3}$ Universidade do Estado de São Paulo, Faculdade de Medicina, Departamento de Neurologia, Psicologia e Psiquiatria, Botucatu SP, Brazil.

Natalia Eduarda FURLAN iD https://orcid.org/0000-0002-8818-6924; Juli Thomaz de SOUZA ID https://orcid.org/0000-0003-2227-7505; Silméia Garcia Zanati BAZAN (ID) https://orcid.org/0000-0002-0607-8189; Roberto Jorge da Silva FRANCO (iD https://orcid.org/0000-0001-9787-4393; Gustavo José LUVIZUTTO ID https://orcid.org/0000-0002-6914-7225; Ana Lúcia GUT (iD) https://orcid.org/0000-0001-5763-0829; Gabriel Pinheiro MODOLO (iD https://orcid.org/0000-0003-1057-5089; Fernanda Cristina WINCKLER (iD) https://orcid.org/0000-0002-7299-5612; Luis Cuadrado MARTIN (iD https://orcid.org/0000-0003-1435-7994; Rodrigo BAZAN iD https://orcid.org/0000-0003-3872-308X

Correspondence: Juli Thomaz de Souza; Departamento de Neurologia, Psicologia e Psiquiatria da UNESP; Distrito de Rubião Junior, s/n; $18618-970$ Botucatu SP, Brazil; E-mail: jtsouz@yahoo.com.br

Conflict of interest: There is no conflict of interest to declare.

Received on February 6, 2019; Received in its final form on September 30, 2019; Accepted on October 8, 2019.
} 
sistólica. Estatinas e inibidores da enzima conversora de angiotensina foram utilizados com maior frequência entre os sobreviventes. Essas associações persistiram mesmo após o ajuste para variáveis de confundimento. Conclusão: 0 uso de estatinas e inibidores da enzima conversora de angiotensina durante a hospitalização foram associados de forma independente à uma menor taxa de mortalidade por todas as causas nos primeiros 7 dias de internação na unidade de terapia intensiva.

Palavras-chave: acidente vascular cerebral; estatina; unidade de terapia intensiva; mortalidade.

Stroke is a prevalent cause of death, especially in intensive care units (ICU) and disabling sequelae in adults worldwide. Among the 15 million worldwide people who have a stroke each year, five million die, and another five million are permanently disabled ${ }^{1-3}$.

Dyslipidemia is a risk factor for stroke, and statins are used for secondary prevention during the chronic phase of the disease ${ }^{4}$.

The Stroke Prevention by Aggressive Reduction of Cholesterol Levels (SPARCL) study evaluated patients with chronic ischemic stroke (IS) and hemorrhagic stroke (HS), and observed a reduction in the incidence of new cerebrovascular events among statin users ${ }^{5}$. However, the hypothesis of a higher incidence of hemorrhagic transformation associated to statin use proposed by Cordenier et al. indicated that statins should be avoided during the acute phase of stroke ${ }^{6}$. Therefore, to test this hypothesis, Blanco et al. ${ }^{7}$ evaluated the effect of withdrawal of statins on mortality during the acute phase of stroke. They found that, as opposed to expectations, the withdrawal of statins increased the probability of death in these patients.

No clinical trial or observational study has yet evaluated the impact of statins during the acute phase of IS in Latin America, particularly in patients admitted to intensive care units (ICU). Therefore, the objective of the present study was to evaluate the association between statin use and all-cause mortality in patients with acute IS during their ICU stay.

\section{METHODS}

In this study, we performed a post-hoc analysis of previous observational and prospective data (CTN: 86920) to evaluate the association between the use of statins and mortality during the acute phase of stroke.

Inclusion criteria were as follows: age $\geq 18$, stroke diagnosis, and admission to the ICUs of the Clinical Hospital of Botucatu Medical School - Universidade Estadual Paulista "Júlio de Mesquita Filho" (UNESP). We excluded patients with missing medical record data.

The following medications were administered to patients during the first 7 days of hospitalization (or according to hospital discharge or death): statins, insulin, noradrenaline, diuretics, beta blockers, sympatholytics, angiotensin converting enzyme inhibitors (ACEI), and sodium nitroprusside. Previous use of these medications was also recorded; the following variables were assessed: age; gender; skin color (self-described by patients); National Institute of Health Stroke Scale (NIHSS) score; blood pressure at admission and every 2 hours thereafter; incidence of acute myocardial infarction (AMI), hemorrhagic transformation, diabetes, high blood pressure, and smoking; These are traditionally associated to worse outcomes.

Data were collected after the informed consents, which were also obtained from the patient's legally authorized representative if the patient could not consent. This study was approved by the Ethics Committee of the Botucatu Medical School.

\section{Statistical analysis}

Sample size was calculated to detect a $30 \%$ difference in lethality rate, with an alpha error of 0.05 and statistical power of 0.8 , thus resulting in an estimated required sample size of 92 patients. Data were analyzed using descriptive statistics, and parametric variables are described as mean \pm standard deviation. The outcome of/ interest was defined as death by any cause in the first week after ICU admission. Data from patients with and without the outcome were compared using the t-test and chi-square test. Variables with $\mathrm{p}<0.1$ were included in the multiple logistic regression analysis as confounders. The dependent variable was the primary outcome, and the association with statin use was adjusted for confounders. Statistical significance was set at $\mathrm{p}<0.05$ for regression analysis.

\section{RESULTS}

There were 1,432 admissions for stroke in our hospital from March 2012 to April 2016. A total of 260 patients required treatment in the ICU. Among the intensive care patients, 48 patients refused to give their informed consent; there were also difficulties obtaining some informed consents. We screened 212 patients, and 66 patients were excluded due to incomplete records. The final sample included 97 patients with ischemic stroke after the exclusion of 49 with hemorrhagic stroke.

The mortality rate among patients who used statins during the acute IS phase [14\% (9/63)] was significantly lower than that of among patients who did not use statins [41\% (14/34); $p=0.007]$. After logistical regression and correction for cofounders, we found an Odds Ratio of 0.19 [p=0.018, 95\%CI 0.05-0.75] for statin use and death in the first 7 days. No significant difference in mortality rates was found 
between patients who used statins prior to the acute phase [(21\%) 4/19] and those who had not used statins previously [24\% (19/78); $\mathrm{p}=1.000]$. Statin was discontinued in 4 patients during the acute phase, none of whom died (0\%), whereas $24 \%(23 / 93)$ of patients without statin discontinuation died $(\mathrm{p}=0.570)$. The mortality rate for patients who received statins [10\% (5/48)] was significantly lower than that of patients who did not receive them [37\% (18/49); $\mathrm{p}=0.005]$. All patients were on mechanical ventilation at ICU admission. No patient was undergoing full anticoagulation. All had prophylaxis for deep venous thrombosis with low-molecular-weight heparin.

The incidence of hemorrhagic transformation was $9 \%(3 / 34)$ among patients who did not take statins, whereas $24 \%(15 / 63)$ of patients who received statins experienced cerebral bleeding $(\mathrm{p}=0.124)$. When analyzing only those who received thrombolytic therapy, there were no significant differences in hemorrhagic transformation rates between groups with or without statins.

The following factors were significantly associated to mortality: older age, a higher incidence of AMI on arrival or during hospitalization, higher NIHSS score and lower systolic blood pressure (SBP) at admission, and lower mean SBP during the first 48 hours after admission. Skin-color, hemorrhagic transformation, and pre-existing diabetes mellitus or arterial hypertension were not associated to mortality. Data regarding variables analyzed and their relationship with mortality are shown in Table 1. Male patients were selected for multiple logistic regression analysis because such gender was associated to a higher incidence of mortality, with a $\mathrm{p}<0.1$. When considering only deaths from cardiovascular causes, there was none in the statin group and 4 in patients who did not received statins, with statistical significance, $\mathrm{p}=0.01$.

Table 1. Clinical characteristics of patients with ischemic stroke according to the mortality outcome.

\begin{tabular}{|c|c|c|c|}
\hline & Primary out & ome (death) & \\
\hline & No $(n=74)$ & Yes $(n=23)$ & p-vatue \\
\hline Age (years) & $65 \pm 12.3$ & $75 \pm 12.6$ & 0.002 \\
\hline Male gender, n (\%) & $45(60.8)$ & $09(39.1)$ & 0.070 \\
\hline White skin color, n (\%) & $63(85.1)$ & $22(95.6)$ & 0.300 \\
\hline SBP at admission & $163 \pm 36$ & $130 \pm 27$ & 0.000 \\
\hline Median SBP 48h & $138 \pm 15$ & $127 \pm 16$ & 0.003 \\
\hline NIHSS score & $15 \pm 6.1$ & $20 \pm 7.2$ & 0.008 \\
\hline AMI, n (\%) & $05(6.6)$ & $07(30.4)$ & 0.002 \\
\hline $\mathrm{DM}, \mathrm{n}(\%)$ & $25(32.4)$ & $08(34.7)$ & 0.931 \\
\hline $\mathrm{AH}, \mathrm{n}(\%)$ & $58(78.3)$ & $16(69.5)$ & 0.390 \\
\hline Smoking, n (\%) & $39(52.7)$ & $09(39.1)$ & 0.178 \\
\hline Hemorrhage, n (\%) & $15(20.2)$ & $03(13)$ & 0.441 \\
\hline
\end{tabular}

SBP: systolic blood pressure; NIHSS: National Institute of Health Stroke Scale; AMI: acute myocardial infarction during hospitalization or admission; DM: history of diabetes mellitus; $\mathrm{AH}$ : history of arterial hypertension. All data were expressed in numbers and percentage, or numbers and standard deviation, when they had a normal distribution.
We also observed that the prevalence of statin and ACEI use was significantly higher among survivors, even after adjusting for confounders. Noradrenaline use was directly associated to higher mortality rates. The use of insulin and beta-blockers was also associated to better outcomes $(\mathrm{p}<0.1)$; therefore, these variables were selected for multiple logistic regression analysis. The results of this analysis are shown in Table 2, which describes the use of medications during ICU admission according to mortality.

Logistic regression analysis with progressive exclusion of variables showed that NIHSS score and age were directly associated to mortality (Table 3). This analysis also revealed that the use of ACEI and statins during hospitalization was inversely associated to death in the first 7 days of ICU admission (Table 3).

\section{DISCUSSION}

In the current observational study, we found that statin use was associated with a lower mortality rate in the first week after IS. Some authors believed that statin use in the acute phase of IS could be hazardous, because some preliminary data indicated that statin use was associated with hemorrhagic transformation. However, in the present study, the use of statins was not associated to a significant increase in the occurrence of hemorrhagic transformation, even among patients who were receiving thrombolytic therapy. Moreover, we found that statins were associated to a reduction in deaths from all causes, even after correcting cofounders, for deaths from neurologic and cardiovascular causes, when analyzed alone. This is probably not related to effects on cholesterol, but rather to other effects related to statins in endothelial and inflammatory homeostasis.

Statins are often used for secondary prophylaxis of stroke; however, evidence that it has effects on endothelial function, hemostasis, inflammation, coronary and cerebral blood flow

Table 2. Medication usage during ICU stay in patients with ischemic stroke, according to mortality outcome.

\begin{tabular}{lccc}
\hline \multirow{2}{*}{ Medications } & \multicolumn{2}{c}{ Primary outcome (death) } & \\
\cline { 2 - 3 } & No $(n=74)$ & Yes (n=23) & \\
\hline Statins, $\mathrm{n}(\%)$ & $54(72.9)$ & $09(39.1)$ & 0.007 \\
\hline Insulin, $\mathrm{n}(\%)$ & $33(44.6)$ & $16(69.5)$ & 0.064 \\
\hline Noradrenaline, $\mathrm{n}(\%)$ & $36(48.6)$ & $19(82.6)$ & 0.009 \\
\hline Diuretics, $\mathrm{n}(\%)$ & $40(54)$ & $10(43.5)$ & 0.517 \\
\hline Beta blockers, $\mathrm{n}(\%)$ & $22(29.7)$ & $02(8.7)$ & 0.078 \\
\hline Sympatholytics, $\mathrm{n}(\%)$ & $08(10.8)$ & $02(8.6)$ & 0.919 \\
\hline ACEI, n (\%) & $33(44.5)$ & $02(8.6)$ & 0.004 \\
\hline Nitroprusside, $\mathrm{n}(\%)$ & $18(24.3)$ & $05(21.7)$ & 0.979 \\
\hline
\end{tabular}

ACEI: angiotensin converting enzyme inhibitors. ICU: Intensive Care Unit. All data were expressed in numbers and percentage. 
suggested a potential benefit in acute stroke ${ }^{8}$. Experimental studies in mice, in which statin was used before or as an acute treatment for experimental stroke, showed a reduction in infarct core and in neuronal injury ${ }^{9,10}$. The mechanism for this neuroprotective effect is not believed to be dependent on the cholesterol metabolism and action that statins have on it. Chen et al. ${ }^{11}$ found angiogenesis and synaptogenesis after atorvastatin use initiated one day after experimental stroke, which suggested better neuroplasticity associated to statin ${ }^{11}$.

Table 3. Results of multiple logistic regression analysis (stepwise backward method) of data on mortality in the first week after ischemic stroke, with the variables selected in univariate analysis.

\begin{tabular}{|c|c|c|c|c|}
\hline & \multirow{2}{*}{$\begin{array}{l}\text { Odds } \\
\text { Ratio }\end{array}$} & \multicolumn{2}{|c|}{$\begin{array}{l}95 \% \text { confidence } \\
\text { interval }\end{array}$} & \multirow{2}{*}{$p$-value } \\
\hline & & Lower & Upper & \\
\hline \multicolumn{5}{|l|}{$1^{\text {st }}$ Step } \\
\hline Age (years) & 1.02 & 0.94 & 1.10 & 0.591 \\
\hline Male gender & 0.28 & 0.05 & 1.47 & 0.133 \\
\hline $\begin{array}{l}\text { SBP at admission } \\
(\mathrm{mmHg})\end{array}$ & 0.98 & 0.96 & 1.01 & 0.233 \\
\hline NIHSS score & 1.10 & 0.96 & 1.267 & 0.151 \\
\hline $\begin{array}{l}\text { Median SBP at } \\
48 \mathrm{~h}(\mathrm{mmHg})\end{array}$ & 0.99 & 0.93 & 1.05 & 0.736 \\
\hline AMI & 4.06 & 0.32 & 50.25 & 0.275 \\
\hline NOR & 2.00 & 0.25 & 15.90 & 0.510 \\
\hline ACEI & 0.22 & 0.02 & 2.77 & 0.243 \\
\hline Beta blockers & 0.34 & 0.02 & 4.94 & 0.431 \\
\hline Statins & 0.13 & 0.02 & 0.80 & 0.028 \\
\hline Insulin & 4.38 & 0.61 & 31.38 & 0.141 \\
\hline \multicolumn{5}{|l|}{$5^{\text {th }}$ Step } \\
\hline Age (years) & 1.07 & 1.01 & 1.14 & 0.030 \\
\hline NIHSS score & 1.11 & 0.99 & 1.24 & 0.054 \\
\hline ACEI & 0.13 & 0.02 & 0.78 & 0.025 \\
\hline Statins & 0.19 & 0.05 & 0.75 & 0.018 \\
\hline
\end{tabular}

NIHSS: National Institute of Health Stroke Scale; SBP: systolic blood pressure; ACEI: Angiotensin converting enzyme inhibitors; AMI: acute myocardial infarction.
A clinical trial found better scores in neurological examination at 3 days after stroke, although not sustained at 90 days, and another trial found worse clinical outcomes associated to statins withdrawal ${ }^{7,12}$. However these data were not confirmed in other trials and small studies.

Older age, higher NIHSS score at admission, lower SBP, and AMI were significantly associated to a higher incidence of all-cause mortality; these data are consistent with those from previous sudies ${ }^{13,14}$. Even when the statin use was adjusted for these confounding variables, the association with improved outcomes remained statistically significant. The use of antihypertensives (ACE inhibitors) was associated to lower mortality. The use of beta-blockers was not associated to lower mortality.

Stroke patients with a history of hypertension experience a rightward shift in their cerebral blood flow self-regulation curve. Thus, reductions of more than $20 \%$ in their diastolic blood pressure should be avoided, because they may compromise brain perfusion. In such cases, the use of ACEI may be advantageous, seen that these drugs can preserve the cerebral blood flow self-regulation ${ }^{15}$. The efficacy of ACEI in the prevention of stroke after the acute phase has been previously demonstrated ${ }^{16}$. Notably, the final logistic regression analysis in the current study revealed that the use of ACEI was associated to lower mortality, which suggests a protective effect of this class of drugs in the acute phase as well. However, this hypothesis needs to be confirmed in future interventional studies.

The main limitation of the current study is its observational design. In addition, this study constitutes a post-hoc analysis of an observational study designed to evaluate the association between blood pressure and lethality, and is, therefore, subject to the inherent bias of this type of analysis. These two listed limitations imply the need to confirm data in interventional studies. Another limitation is that the TOAST classification, the circulation or topography of the stroke and if it was a malignant one were not considered in the multivariate analyses. Sample size, although small, was enough to demonstrate the statistical associations that were investigated.

In conclusion, the use of statins and ACEI during the acute phase of IS in patients admitted to the ICU was associated to a lower mortality rate, even after adjusting age, NIHSS score, and ACEI use. Randomized, controlled trials with a larger sample size are warranted to determine the efficacy of statins in reducing mortality during the acute phase of stroke.

\section{References}

1. Grysiewicz RA, Thomas K, Pandey DK. Epidemiology of Ischemic and Hemorrhagic Stroke: Incidence, Prevalence, Mortality, and Risk Factors. Neurol Clin. 2008 Nov;26(4):871-95. https://doi. org/10.1016/j.ncl.2008.07.003

2. Garritano CR, Luz PM, Pires MLE, Barbosa MTS, Batista KM. Análise da tendência da mortalidade por acidente vascular cerebral no Brasil no século XXI. Arq Bras Cardiol. 2012;98(6):519-27. http://dx.doi. org/10.1590/S0066-782X2012005000041
3. Instituto Brasileiro de Geografia e Estatística. Sistema de Informação Hospitalar do Sistema Único de Saúde (SIH/SUS). Brasilia: IBGE; 2009. Available from: http://ces.ibge.gov.br/pt/base-de-dados/ metadados/ministerio-da-saude/sistema-de-informacoeshospitalares-do-sus-sih-sus.

4. Xavier HT, Izar MC, Faria Neto JR, Assad MH, Rocha VZ, Sposito AC, et al. V Diretriz Brasileira de Dislipidemias e Prevenção da Aterosclerose. Arq Bras Cardiol. 2013;101(4):1-20. http://dx.doi.org/10.5935/abc.2013S010 
Amarenco P, Bogousslavsky J, Callahan A 3rd, Goldstein LB, Hennerici M, Rudolph AE, et al. Stroke Prevention by Aggressive Reduction in Cholesterol Levels (SPARCL) Investigators. High-dose atorvastatin after stroke or transient ischemic attack. N Engl J Med. 2006;355(6):549-59. http://dx.doi.org/10.1056/NEJMoa061894

6. Cordenier A, De Smedt A, Brouns R, Uyttenboogaart M, De Raedt S, Luijckx GJ, et al. Pre-stroke use of statins on stroke outcome: a meta-analysis of observational studies. Acta Neurol Belg. 2011 Dec;111(4):261-7.

7. Blanco M, Nombela F, Castellanos M, Rodriguez-Yáñez M, García-Gil M, Leira R, et al. Statin treatment withdrawal in ischemic stroke: a controlled randomized study. Neurology 2007;69(9):904-10.

8. Elkind MSV, Sacco RL, MacArthur RB, Peerschke E, Neils G, Andrews $\mathrm{H}$, et al. High-dose lovastatin for acute ischemic stroke: results of the phase I dose escalation neuroprotection with statin therapy for acute recovery trial (NeuSTART). Cerebrovasc Dis. 2009 Aug;28(3):266-75. http://dx.doi.org/10.1159/000228709

9. Amin-Hanjani S, Stagliano NE, Yamada M, Huang PL, Liao JK, Moskowitz MA. Mevastatin, an HMG-CoA reductase inhibitor, reduces stroke damage and upregulates endothelial nitric oxide synthase in mice. Stroke. 2001 Apr;32(4):980-6. https://doi.org/10.1161/01. str.32.4.980

10. Laufs U, Gertz K, Dirnagl U, Böhm M, Nickenig G, Endres M. Rosuvastatin, a new HMG-CoA reductase inhibitor, upregulates endothelial nitric oxide synthase and protects from ischemic stroke in mice. Brain Res. 2002 Jun;942(1-2):23-30. https://doi.org/10.1016/ s0006-8993(02)02649-5

11. Chen J, Zhang ZG, Li Y, Wang Y, Wang L, Jiang H, et al. Statins induce angiogenesis, neurogenesis, and synaptogenesis after stroke. Ann Neurol. 2003 Jun;53(6):743-51. https://doi.org/10.1002/ana.10555

12. Montaner J, Chacón P, Krupinski J, Rubio F, Millán M, Molina CA, et al. Simvastatin in the acute phase of ischemic stroke: a safety and efficacy pilot trial. Eur J Neurol. 2008 Jan;15(1):82-90. https://doi. org/10.1111/j.1468-1331.2007.02015.x

13. Costa FA, Silva DLA, da Rocha VM. Estado neurológico e cognição de pacientes pós-acidente vascular cerebral. Rev Esc Enferm USP. 2011;45(5):1083-8. http://dx.doi.org/10.1590/S008062342011000500008

14. Martins SC, Brondani R, Frohlich AC, Castilhos RM, Dallalba CC, Brugnera J, et al. Trombólise no AVCl agudo em um Hospital da Rede Pública: a experiência do Hospital de Clínicas de Porto Alegre. Rev Neurocienc. 2007;15(3):219-25.

15. Sociedade Brasileira de Cardiologia, Sociedade Brasileira de Nefrologia. III Consenso brasileiro de hipertensão arterial. Arq Bras Endocrinol Metab. 1999;43(4):257-86. http://dx.doi.org/10.1590/ S0004-27301999000400002

16. Gagliardi RJ, André C, Fukujima MM, Melo-Souza SE, Zétola VF. Abordagem da doença carotídea na fase aguda do acidente vascular cerebral: opinião nacional. Arq Neuropsiquiatr. 2005;63(3A):709-12. http://dx.doi.org/10.1590/S0004-282X2005000400032 